\title{
Pengaruh Visual Aesthetics dan Presentation Modality Terhadap Information Credibility, Consumer Trust, dan Purchase Intention
}

\author{
Antariksa Wibawa Natanegara \\ Universitas Airlangga \\ e-mail: antariksawibawanatanegara@gmail.com
}

\begin{abstract}
This study analyzes how visual aesthetics and presentation modality influence information credibility, consumer trust and purchase intention on food content. This research uses a quantitative approach and belongs to the category of causal studies. The sampling technique used is nonprobability sampling. The sample of this research is people who actively use Instagram, follow culinary accounts, have bought food products on Instagram. Data collection techniques through surveys with a questionnaire that uses a five-level Likert scale. The questionnaire was distributed via an electronic link using Google form. The analysis technique used is Manova and Sem. The results of this study stated that visual aesthetic and presentation modality affect information credibility and consumer trust, then information credibility and consumer trust affect purchase intention.
\end{abstract}

Keywords: visual aesthetics, presentation modality, Manova, Sem

\section{PENDAHULUAN}

Instagram saat ini menjadi salah satu media sosial yang populer di Indonesia. Beberapa hal yang menyebabkan Instagram menjadi semakin populer karena adanya langkah-langkah berani yang dilakukan oleh Facebook selaku pemilik baru Instagram. Semenjak mengakuisisi Instagram, Facebook telah melakukan beberapa penambahan fitur pada Instagram, seperti menambah resolusi foto, memperbanyak filter foto, menambah filter video yang awalnya hanya berdurasi 15 detik menjadi berdurasi satu menit, menambahkan fitur multiple post, dan lain-lain. Instagram juga menghadirkan berbagai macam fitur terbaru yang mendukung kegiatan bisnis seperti Instastory, Instagram Advertising, serta dapat mengubah akun biasa menjadi akun bisnis sehingga dapat melihat insight dari setiap postingan yang diunggah.

Fungsi Instagram saat ini tidak lagi sebatas media komunikasi personal namun juga sebagai platform bagi pemasar untuk melakukan kegiatan bisnis (Kompasiana, 2019). Instagram memiliki fitur khusus bagi akun bisnis seperti mengetahui demografi pengguna bagi yang melihat akun bisnis tersebut dan mengetahui jumlah penonton dari akun bisnis tersebut serta mengetahui jumlah pengikut dari akun bisnis tersebut. Dengan fitur pendukung tersebut, pemasar dapat mengoptimalkan promosi penjualan dan dapat membantu pemasar dalam melakukan promosi produk. Hal ini juga didukung dengan tingginya antusias masyarakat Indonesia pada jejaring sosial ini di mana Instagram memasuki urutan keempat dalam jejaring sosial yang paling aktif digunakan oleh masyarakat Indonesia (Hootsuite, 2020).

Saat ini, banyak bermunculan bisnis makanan yang memanfaatkan akun social media untuk mengiklankan produknya. Pelaku bisnis makanan harus memperhatikan kegunaan social media yang sesuai dengan target pasarnya sehingga pesan yang diberikan efektif, efisien, dan memenuhi tujuan dari penggunaannya. Ada beberapa hal yang melatarbelakangi mencuatnya bisnis 
makanan di social media, antara lain terjadinya perubahan gaya hidup konsumen urban Indonesia yang signifikan. Konsumen urban Indonesia kini menghabiskan lebih banyak waktu di luar rumah, menikmati lebih banyak aktivitas, dan berupaya untuk mencari lebih banyak pengalaman. Kelas konsumen ini pada umumnya saling terkoneksi, gesit, terekspos pada informasi, dan terbuka untuk mencoba hal-hal baru. Meningkatnya gaya hidup urban yang aktif membuat konsumen lebih banyak menghabiskan waktu di luar rumah. Gaya hidup ini memberikan perubahan signifikan terhadap perilaku konsumen dalam mengalokasikan pengeluaran mereka, terutama untuk produk-produk siap santap (ready to eat atau RTE) dan minuman dalam kemasan (ready to drink atau RTD) (PikiranRakyat.com, 2019).

Seperti yang telah dijelaskan bahwa dengan begitu banyaknya pengguna di Instagram, berakibat pada banyaknya jumlah postingan. Saat ini tercatat sekitar 95 juta gambar yang diunggah setiap harinya. Dari sudut pandang pelaku bisnis, traffic 95 juta post di Instagram tentu menjadi tantangan, agar postingan mereka mampu menarik perhatian pengguna Instagram, karena tercatat sekitar 70\% unggahan konten di Instagram tidak dilihat bahkan diabaikan oleh pengguna (Digital Business, 2018).

Adanya intensitas unggahan konten pada timeline pengguna Instagram menyebabkan adanya penumpukan konten yang tidak tersaring. Hal ini menjadi tantangan bagi pelaku usaha makanan dalam merancang strategi konten iklan yang tepat. Apabila tidak, kemungkinan besar konten tersebut tidak dilihat atau bahkan diabaikan begitu saja oleh para pengikut dan pengguna Instagram lainnya (Femaledaily.com, 2018).

Nekmat dan Gower (2012) mengatakan bahwa niat beli (purchase intention) muncul pada konsumen, disebabkan oleh beberapa faktor di antaranya ialah informasi yang detail pada iklan, sosok yang dipercaya oleh konsumen untuk menyampaikan informasi tersebut dan informasi yang terlihat kredibel (dianggap memiliki kredibilitas yang baik). Ketika informasi iklan tersebut memiliki pesan yang jelas dan dianggap kredibel muncul rasa percaya konsumen bahwa yang disampaikan oleh iklan tersebut adalah benar, dari situlah akan muncul niat untuk membeli oleh konsumen. Ismagilova, E., et al. (2019) juga menemukan hal yang sama. Niat beli muncul ketika konsumen mendapatkan informasi iklan dari seseorang yang dianggap memiliki kompetensi pada bidang itu.

Ada beberapa teori yang dapat memengaruhi sebuah iklan pemasaran yang dapat menimbulkan kesan kredibel dan meningkatkan rasa percaya pada produk yang diiklankan yaitu visual aesthetetics dan presentation modality. Elemen desain visual adalah salah satu faktor signifikan yang memengaruhi persepsi konsumen (Van Rompay, et al., 2012). Orang-orang mulai memasukkan komponen estetika dalam setiap aspek kehidupan karenanya; istilah estetika mengambil bagian dalam kehidupan sehari-hari dari banyak orang (Weggeman, et al., 2007; Venkatesh dan Meamber, 2008). Untuk alasan ini, perusahaan dan manajer mencoba untuk membedakan produk mereka dengan memasukkan unsur estetika agar produk mereka laris.

Meskipun penggunaan jenis visual aesthetics dan presentation modality saat ini banyak ditampilkan pada iklan-iklan di media sosial seperti Instagram, hasil penelitian empiris tentang efektivitasnya masih belum banyak diperoleh. Kemudian, masih terbatasnya penelitian yang menguji efektivitas visual aesthetics (classical vs expressive) dan presentation modality (single vs multiple) pada konten periklanan produk makanan yang diunggah di Instagtram. Temuan penelitian ini dapat memberikan kontribusi penting bagi pemasar dalam pengembangan 
strategi kegiatan pemasaran pada media sosial, terutama Instagram serta dapat memberikan kontribusi bagi pemilik usaha makanan dalam merancang konten yang akan ditampilkan.

Melalui penelitian ini, peneliti ingin menguji apakah penggunaan jenis visual aesthetics dan presentation modality dalam tampilan konten periklanan yang diunggah oleh pelaku usaha makanan di Instagram akan mampu menghasilkan respons paling efektif pada credibility information, consumer trust, dan purchase intention.

\section{KERANGKA KONSEPTUAL}

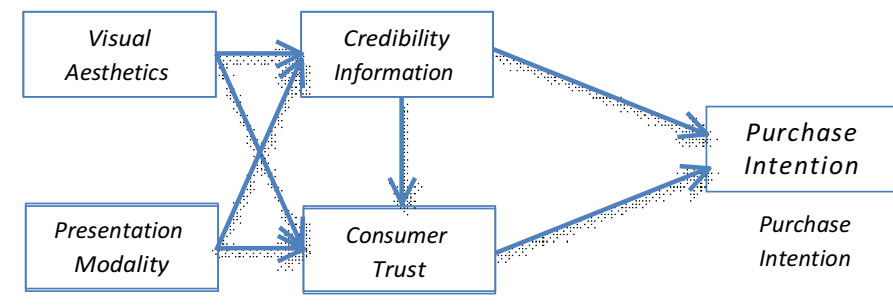

\section{METODE PENELITIAN}

Penelitian ini menggunakan pendekatan kuantitatif dan termasuk dalam kategori studi kausal. Teknik pengambilan sampel yang digunakan adalah non-probability sampling. Sampel penelitian ini adalah orang-orang yang aktif menggunakan Instagram, mem-follow akun kuliner, pernah membeli produk makanan yang ada di Instagram. Teknik pengumpulan data melalui survei dengan kuesioner yang menggunakan skala likert lima tingkat. Kuesioner tersebut disebarkan melalui tautan elektronik dengan menggunakan Google form. Teknik analisis yang digunakan adalah Manova dan Sem.

\section{HASIL PENELITIAN}

Penelitian ini melibatkan 120 orang responden yang terbagi atas empat kelompok dengan perlakuan berbeda beda di mana pada masing- masing kelompok terdiri atas 30 orang. Keempat kelompok yang dipergunakan dalam penelitian dibedakan berdasarkan stimuli yang mendasari pengisian kuesioner. Stimuli yang dipergunakan adalah foto, video, atau keduanya yang meliputi foto visual aesthetics classical, foto visual aesthetics expressive, video aesthetics classical, dan video aesthetics expressive. Jumlah responden dengan jenis kelamin perempuan memiliki jumlah yang lebih besar sebanyak 67 orang $(55,8 \%)$ yang merata pada setiap kelompok responden, kecuali untuk kelompok responden video aesthetics classical yang lebih banyak responden laki-laki. Sementara itu, untuk responden lakilaki sendiri memiliki jumlah keseluruhan sebanyak 53 orang $(44,2 \%)$.

Jumlah responden dengan usia antara 26 hingga 35 tahun memiliki jumlah yang paling besar dibandingkan kategori usia yang lainnya baik secara kelompok maupun secara total responden. Tercatat sebanyak 78 orang $(65,0 \%)$ responden berusia 26-35 tahun. Kemudian responden dengan usia 18-25 tahun tercatat sebanyak 36 orang $(30,0 \%)$ dan sisanya masingmasing sebanyak tiga orang $(2,5 \%)$ adalah responden yang berusia antara 36-45 tahun serta 46-55 tahun. Jumlah responden yang memiliki profesi sebagai swasta merupakan responden dengan jumlah yang paling besar sebanyak 58 orang $(48,3 \%)$ merata pada semua kelompok terkecuali untuk kelompok video aesthetics classical. Responden yang berprofesi sebagai pelajar/ mahasiswa sebanyak 29 orang (24,2\%), PNS sebanyak sembilan orang $(7,5 \%)$, dan wiraswasta sebanyak 17 orang (14,2\%). Disusul oleh responden berprofesi sebagai ibu rumah tangga sebanyak lima orang $(4,2 \%)$ dan profesi lainlain sebanyak dua orang $(1,7 \%)$.

Jumlah responden yang memiliki pendidikan terakhir setara dengan Strata 1 (S1) dengan jumlah sebanyak 78 orang $(65,0 \%)$ dan merata 
pada setiap kelompok responden. Responden lain adalah berpendidikan akhir SMA sebanyak 28 orang (23,3\%), S2 sebanyak 13 orang (10,8\%), dan SMP hanya satu orang (0,8\%). Sebagian besar responden adalah orang yang berpenghasilan antara Rp 2,5-7,5 juta berjumlah 78 orang
(65,0\%) dengan proporsi merata pada semua kelompok responden. Responden terbanyak kedua adalah yang berpenghasilan antara $\mathrm{Rp} 7,6$ juta hingga Rp 15 juta sebanyak 36 orang (30,0\%). Sementara itu, sisanya adalah responden dengan penghasilan antara Rp 16 juta hingga

Tabel 1 Jawaban Responden

\begin{tabular}{|c|c|c|c|c|c|}
\hline \multirow[b]{2}{*}{ Item } & \multirow[b]{2}{*}{ Pernyataan } & \multicolumn{4}{|c|}{ Mean } \\
\hline & & $\begin{array}{c}\text { Foto } \\
\text { Classical } \\
\end{array}$ & $\begin{array}{c}\text { Foto } \\
\text { Expressive }\end{array}$ & $\begin{array}{l}\text { Video } \\
\text { Classical }\end{array}$ & $\begin{array}{c}\text { Video } \\
\text { Expressive }\end{array}$ \\
\hline IC1 & $\begin{array}{l}\text { Desain postingan pada ma- } \\
\text { kanan tersebut sesuaidengan } \\
\text { selera saya }\end{array}$ & 3,37 & 2,90 & 3,87 & 4,13 \\
\hline IC2 & $\begin{array}{l}\text { Postingan makanan tersebut } \\
\text { terlihatprofesional }\end{array}$ & 3,40 & 2,87 & 4,10 & 3,73 \\
\hline IC3 & $\begin{array}{l}\text { Postingan makanan tersebut } \\
\text { terlihat autentik/apa adanya }\end{array}$ & 3,37 & 2,93 & 4,13 & 4,13 \\
\hline IC4 & $\begin{array}{l}\text { Postingan makanan tersebut } \\
\text { menarikperhatian saya }\end{array}$ & 3,40 & 2,90 & 4,13 & 4,03 \\
\hline \multicolumn{2}{|c|}{ Mean Kelompok } & 3,39 & 2,90 & 4,06 & $\begin{array}{c}4,0 \\
1 \\
\end{array}$ \\
\hline \multicolumn{2}{|c|}{ Mean Total } & \multicolumn{4}{|c|}{3,59} \\
\hline CT1 & $\begin{array}{l}\text { Postingan makanan tersebut } \\
\text { dapat dipercaya }\end{array}$ & 3,43 & 2,77 & 4,27 & 4,23 \\
\hline CT2 & $\begin{array}{l}\text { Postingan makanan tersebut } \\
\text { persuasif dan meyakinkan saya }\end{array}$ & 3,47 & 2,87 & 4,30 & 4,13 \\
\hline CT3 & $\begin{array}{l}\text { Postingan makanantersebut } \\
\text { tidak meragukan saya }\end{array}$ & 3,37 & 2,87 & 4,30 & 4,30 \\
\hline \multicolumn{2}{|c|}{ Mean Kelompok } & 3,42 & 2,84 & 4,29 & 4,22 \\
\hline \multicolumn{2}{|c|}{ Mean Total } & \multicolumn{4}{|c|}{3,69} \\
\hline PI1 & $\begin{array}{l}\text { Saya akan membelimakanan } \\
\text { yang diiklankan tersebut }\end{array}$ & 3,37 & 2,93 & 4,10 & 4,27 \\
\hline PI2 & $\begin{array}{l}\text { Saya akan mempertimbangkan } \\
\text { untuk membeli makananyang } \\
\text { diiklankan tersebut suatu saat } \\
\text { nanti }\end{array}$ & 3,33 & 3,00 & 4,20 & 4,30 \\
\hline PI3 & $\begin{array}{l}\text { Saya bersedia untuk membeli } \\
\text { makanan yang diiklankan } \\
\text { tersebut }\end{array}$ & 3,43 & 2,90 & 4,27 & 4,30 \\
\hline PI4 & $\begin{array}{l}\text { Saya memiliki keinginan untuk } \\
\text { membeli makanan yang di- } \\
\text { iklankan tersebut }\end{array}$ & 3,43 & 2,90 & 4,20 & 4,10 \\
\hline PI5 & $\begin{array}{l}\text { Kemungkinan besar saya akan } \\
\text { membeli makanan yang di- } \\
\text { iklankan tersebut dalam waktu } \\
\text { dekat }\end{array}$ & 3,20 & 2,90 & 4,13 & 4,10 \\
\hline \multirow{2}{*}{\multicolumn{2}{|c|}{$\begin{array}{l}\text { Mean Kelompok } \\
\text { Mean Total }\end{array}$}} & 3,35 & 2,93 & 4,18 & 4,21 \\
\hline & & \multicolumn{4}{|c|}{3,67} \\
\hline
\end{tabular}


Tabel 2 Hasil Uji Beda Manova Visual Aesthetics

\begin{tabular}{|l|l|c|c|c|c|}
\hline \multirow{2}{*}{ Variabel } & \multirow{2}{*}{ Kelompok } & \multirow{2}{*}{ Mean } & \multicolumn{2}{|c|}{ DifferenceTest } & \multirow{2}{*}{ Keterangan } \\
\cline { 4 - 5 } & & & F test & Sig & \\
\hline $\begin{array}{l}\text { Information } \\
\text { credibility }\end{array}$ & Single & 12,567 & 75,934 & 0,000 & Ada Beda \\
\cline { 2 - 3 } $\begin{array}{l}\text { Consumer } \\
\text { Trust }\end{array}$ & Multiple & 16,133 & & & \\
\cline { 2 - 3 } & Single & 9,383 & 96,337 & 0,000 & Ada Beda \\
\hline
\end{tabular}

Rp 20 juta sebanyak lima orang (4,2\%) dan penghasilan lebih dari Rp 25 juta sebanyak satu orang $(0,8 \%)$.

Multivariate analysis of variance (Manova) adalah penelitian yang dipergunakan untuk mengetahui adanya perbedaan tanggapan responden pada variabel information credibility serta consumer trust dengan adanya dua stimuli yang dipergunakan yaitu visual aesthetics classical dan expressive serta presentation modality single dan multiple.

Berdasarkan hasil analisis Manova pada Tabel 2, untuk variabel information credibility diperoleh nilai $F$ hitung ( $F$ test) sebesar 6,792 dengan nilai signifikan sebesar 0,010 . Hasil nilai signifikansi 0,010 lebih kecil dibandingkan 0,05 sehingga dapat disimpulkan bahwa terdapat perbedaan yang signifikan pada information credibility responden yang diberikan stimuli visual aesthetics classical dan expressive. Lebih lanjut dapat diinformasikan bahwa persepsi information credibility responden dengan stimuli visual aesthetics classical lebih bagus dibandingkan dengan responden yang diberikan stimuli visual aesthetics expressive. Melalui hasil uji ini dapat dikemukakan hipotesis pertama (H1) dapat dibuktikan secara statistik.

Berdasarkan hasil analisis Manova pada Tabel 2, untuk variabel consumer trust diperoleh nilai $\mathrm{F}$ hitung ( $\mathrm{F}$ test) sebesar 8,138 dengan nilai signifikan sebesar 0,005 . Hasil nilai signifikansi 0,005 lebih kecil dibandingkan 0,05 sehingga dapat disimpulkan bahwa terdapat perbedaan yang signifikan pada consumer trust responden yang diberikan stimuli visual aesthetics classical dan expressive. Lebih lanjut dapat diinformasikan bahwa persepsi consumer trust responden dengan stimuli visual aesthetics classical juga masih lebih bagus dibandingkan dengan responden yang diberikan stimuli visual aesthetics expressive. Melalui hasil uji ini dapat dikemukakan hipotesis kedua (H2) dapat dibuktikan secara statistik.

Berdasarkan hasil analisis Manova pada Tabel 3, untuk variabel information credibility diperoleh nilai $\mathrm{F}$ hitung (F test) sebesar 75,934 dengan nilai signifikan sebesar 0,000 . Hasil nilai signifikansi 0,000 lebih kecil dibandingkan 0,05 sehingga dapat disimpulkan bahwa terdapat

Tabel 3 Hasil Uji Beda Manova Presentation Modality

\begin{tabular}{|l|l|c|c|c|c|}
\hline \multirow{2}{*}{ Variabel } & \multirow{2}{*}{ Kelompok } & \multirow{2}{*}{ Mean } & \multicolumn{2}{|c|}{ DifferenceTest } & \multirow{2}{*}{ Keterangan } \\
& & & F test & Sig & \\
\hline $\begin{array}{l}\text { Information } \\
\text { credibility }\end{array}$ & Single & 12,567 & 75,934 & 0,000 & Ada Beda \\
\cline { 2 - 3 } & Multiple & 16,133 & & & \\
\hline $\begin{array}{l}\text { Consumer } \\
\text { Trust }\end{array}$ & Single & 9,383 & 96,337 & 0,000 & Ada Beda \\
\cline { 2 - 3 } & Multiple & 12,767 & & & \\
\hline
\end{tabular}


perbedaan yang signifikan pada information credibility responden yang diberikan stimuli presentation modality single dan multiple. Lebih lanjut dapat diinformasikan bahwa persepsi information credibility responden dengan stimuli presentation modality multiple lebih bagus dibandingkan dengan responden yang diberikan stimuli presentation modality single. Melalui hasil uji ini dapat dikemukakan hipotesis ketiga (H3) dapat dibuktikan secara statistik.

Berdasarkan hasil analisis Manova pada Tabel 3, untuk variabel consumer trust diperoleh nilai $F$ hitung ( $F$ test) sebesar 96,337 dengan nilai signifikan sebesar 0,000 . Hasil nilai signifikansi 0,000 lebih kecil dibandingkan 0,05 sehingga dapat disimpulkan bahwa terdapat perbedaan yang signifikan pada consumer trust responden yang diberikan stimuli presentation modality single dan multiple. Lebih lanjut dapat diinformasikan bahwa persepsi consumer trust responden dengan stimuli presentation modality multiple lebih bagus dibandingkan dengan responden yang diberikan stimuli presentation modality single. Melalui hasil uji ini dapat dikemukakan hipotesis keempat $(\mathrm{H} 4)$ dapat dibuktikan secara statistik.

Berdasarkan Tabel 4 tersebut dapat diketahui beberapa hal sebagai berikut.

1. Besar pengaruh antara information credibility terhadap consumer trust adalah sebesar 0,778 dengan nilai $p$ sebesar 0,000 yang nilainya lebih kecil dari $0,05(\alpha=5 \%)$ sehingga dapat disimpulkan bahwa information credibility berpengaruh signifikan terhadap consumer trust. Berdasarkan hasil ini maka hipotesis kelima penelitian (H5) yang menduga information credibility berpengaruh signifikan terhadap consumer trust dapat diterima dan terbukti secara statistik.

2. Besar pengaruh antara information credibility terhadap purchase intention adalah sebesar 0,351 dengan nilai $p$ sebesar 0,000 yang nilainya lebih kecil dari $0,05(\alpha=5 \%)$, sehingga dapat disimpulkan bahwa information credibility berpengaruh signifikan terhadap purchase intention. Berdasarkan hasil ini, maka hipotesis keenam penelitian (H6) yang menduga information credibility berpengaruh signifikan terhadap purchase intention dapat diterima dan terbukti secara statistik.

3. Besar pengaruh antara consumer trust terhadap purchase intention adalah sebesar 0,593 dengan nilai $p$ sebesar 0,000 yang nilainya lebih kecil dari 0,05 ( $\alpha=5 \%)$, sehingga dapat disimpulkan bahwa consumer trust berpengaruh signifikan terhadap purchase intention. Berdasarkan hasil ini, maka hipotesis ketujuh penelitian (H7) yang menduga consumer trust berpengaruh signifikan terhadap purchase intention dapat diterima dan terbukti secara statistik.

Tabel 4 Uji Pengaruh Sem

\begin{tabular}{|c|c|c|c|c|c|c|}
\hline \multicolumn{3}{|c|}{ Pengaruh } & Estimate & SE & C.R. & $\mathrm{P}$ \\
\hline $\begin{array}{l}\text { Information } \\
\text { Credibility }\end{array}$ & $\rightarrow$ & Consumer Trust & 0,778 & 0,104 & 9,114 & 0,000 \\
\hline $\begin{array}{l}\text { Information } \\
\text { Credibility }\end{array}$ & $\rightarrow$ & Purchase Intention & 0,351 & 0,120 & 3,578 & 0,000 \\
\hline Consumer Trust & $\rightarrow$ & Purchase Intention & 0,593 & 0,099 & 6,017 & 0,000 \\
\hline
\end{tabular}




\section{DISKUSI}

\section{Perbedaan Visual Aesthetics terhadap Informa- tion Credibility dan Consumer Trust}

Berdasarkan hasil penelitian, dapat diketahui bahwa perbedaan jenis visual aesthetics memiliki pengaruh yang berbeda terhadap information credibility dan consumer trust. Hasil ini didasarkan pada hasil pengujian menggunakan Manova, dengan demikian hipotesis 1 dan 2 dapat diterima, yang mengindikasikan bahwa ada perbedaan respons dari partisipan ketika melihat visual aesthetics yang berbeda, pada variable information credibility dan consumer trust, didapatkan hasil visual aesthetics classical memiliki nilai yang lebih tinggi dibandingkan visual aesthetics expressive, dengan kata lain partisipan lebih menyukai foto makanan yang rapi, simpel, dan minimalis dibandingkan foto makanan yang acak dan tidak teratur.

Hal ini sejalan dengan penelitian yang dilakukan oleh (Kensicki, L.J., 2003), yang membandingkan desain visual website mana yang paling dianggap memiliki kredibilitas menunjukkan hasil, menurut responden website yang menggunakan desain simpel dan minimalis dianggap paling kredibel (78.9\% dibandingkan dengan website yang hanya memiliki tulisan dan $69.2 \%$ dibandingkan dengan website yang menggunakan desain tidak teratur atau rumit).

Perbedaan presentation modality terhadap information Credibility dan Consumer Trust

Berdasarkan hasil penelitian, dapat diketahui bahwa perbedaan jenis presentation modality memiliki pengaruh yang berbeda terhadap information credibility dan consumer trust. Hasil ini didasarkan pada hasil pengujian menggunakan Manova, dengan demikian hipotesis 3 dan 4 dapat diterima, yang mengindikasikan bahwa ada perbedaan respons dari partisipan ketika melihat media yang berbeda, dalam hal ini ialah media foto dan video. Didapatkan hasil bahwa konten video atau multiple presentation modality memiliki nilai yang lebih tinggi dibandingkan dengan konten foto atau single presentation modality terhadap information credibility dan consumer trust. Studi dari penelitian Burgoon et al., (2008) juga membenarkan bahwa tampilan iklan dengan multiple presentation modality dapat meningkatkan kredibilitas yang lebih besar serta kepercayaan kepada iklan dalam pertukaran komunikasi. Maka dari itu, sebuah pesan yang ditampilkan dengan multiple presentation modality, maka iklan tersebut akan dianggap semakin kredibel oleh konsumen.

Semakin banyak presentation modality yang digunakan dalam hal ini pada konten periklanan yang diciptakan oleh pelaku usaha, maka akan mengurangi ambiguitas dan ketidakpastian pada sebuah pesan yang disampaikan dibandingkan dengan tampilan single presentation modality. Konsumen akan menganggap iklan kredibel ketika konten yang disajikan dengan tampilan multiple presentation modality dibandingkan dengan konten dengan tampilan single presentation modality. Information credibility sangat memengaruhi proses penerimaan pesan yang diterima oleh konsumen (Friedman dan Friedman, 1979 dalam Hunt, 2000).

\section{Information Credibility dan Consumer Trust}

Hasil pengujian yang telah dilakukan dengan SEM AMOS menunjukkan bahwa information credibility dapat memengaruhi consumer trust secara positif dan signifikan sehingga menjadikan hipotesis 5 terdukung pada penelitian ini. Hasil dari penelitian tersebut menyatakan bahwa sebu- 
ah iklan yang dianggap memiliki kredibilitas yang tinggi dapat berfungsi sebagai dasar penting dalam evaluasi iklan bagi konsumen. Secara umum, pesan yang disampaikan oleh sumber yang memiliki kredibilitas tinggi akan diterima lebih mudah oleh konsumen dan lebih memungkinkan untuk mengarah pada pembentukan sikap yang lebih positif (Kelman dan Hovland, 1953; Johnson, Torcivia, dan Poprick, 1968; Miller dan Baseheart, 1969; Warren, 1969; Schulman dan Worrall, 1970 dalam Goldsmith, 2002). Oleh karena itu, iklan yang dianggap kredibel telah terbukti memiliki efek positif pada pembentukan sikap percaya konsumen terhadap iklan (Atkin dan Blok, 1983; Fishbein dan Ajzen, 1975; Goldberg dan Hartwick, 1990; Mitchell dan Olson, 1981 dalam Goldsmith, 2002). Dengan demikian menunjukkan bahwa information credibility memang berhubungan positif dengan rasa percaya terhadap iklan (Goldsmith, et al., 2002).

\section{Information Credibility dan Purchase Intention}

Hasil pengujian yang telah dilakukan dengan Sem Amos menunjukkan bahwa information credibility dapat memengaruhi purchase intention secara positif dan signifikan sehingga menjadikan hipotesis 6 terdukung pada penelitian ini. Hal ini sejalan dengan teori Goldsmith yang mengatakan iklan yang dianggap kredibel akan membentuk adanya efek positif terhadap persepsi konsumen atas sebuah pesan atau informasi yang disampaikan (Goldsmith, et al., 2000 dalam Lim, et al., 2017). Selain itu, iklan yang memiliki desain yang baik dan menarik akan cenderung lebih persuasif dalam menyampaikan pesan kepada konsumen (Aaker dan Myers, 1987 dalam Lim, et al., 2017) dan mampu mendorong niat pembelian konsumen (Ohanian 1991 dalam
Lim, et al., 2017). Hal ini kemudian sejalan dengan penelitian terdahulu yang menyatakan bahwa credibility information memiliki pengaruh positif pada sikap konsumen serta niat membeli (Till dan Busler, 2000 dalam Lim, et al., 2017).

Metzger et al. (2003) menjelaskan bahwa informasi yang dianggap memiliki trustworthy yang tinggi akan membuat konsumen tertarik terhadap pesan yang disampaikan dalam iklan sehingga penerimaan informasi akan mencakup aspek yang lebih luas sehingga dapat berpengaruh pada perilaku pengikut mereka. Informasi dengan tingkat attractiveness yang tinggi juga dapat memicu adanya sikap positif dari konsumen dengan munculnya niat pembelian (Till dan Busler, 2000 dalam Lim, et al., 2017). Oleh karena itu, informasi yang dianggap memiliki kredibilitas tinggi akan memicu niat beli pada konsumen.

\section{Consumer Trust dan Purchase Intention}

Hasil pengujian yang telah dilakukan dengan Sem Amos menunjukkan bahwa consumer trust dapat memengaruhi purchase intention secara positif dan signifikan sehingga menjadikan hipotesis 7 terdukung pada penelitian ini. Hasil ini sejalan dengan beberapa penelitian terdahulu yang menyatakan bahwa dengan sikap percaya terhadap iklan maka akan memiliki pengaruh yang signifikan terhadap niat beli (Karson dan Fisher, 2005b; Lord, Lee, dan Sauer, 1995 dalam Huang, et al., 2017). Selain itu, sikap terhadap iklan cenderung memicu adanya pandangan secara subjektif sehingga akan mengarah pada sikap impersonal pada konsumen yang akan memicu adanya niat beli (MacKenzie, et al., 1986 dalam Huang, et al., 2017). Oleh karena itu, dengan adanya sikap percaya terhadap iklan akan memicu adanya niat beli pada konsumen. 
Kepercayaan dapat mengeliminasi perasaan akan ketidakpastian yang dirasakan oleh konsumen ketika bertransaksi dengan toko yang belum pernah dikenal, kualitas yang belum teruji. Lebih lanjut, Heijden, et al. (2003) mengemukakan bahwa trust dapat mengurangi risiko-risiko yang konsumen akan terima (perceived risk) jika bertransaksi secara online sehingga hal ini dapat memengaruhi minat beli secara positif.

\section{KESIMPULAN}

Berdasarkan analisis dan pembahasan yang telah dilakukan pada bab sebelumnya, maka simpulan yang dapat diambil dalam penelitian ini adalah sebagai berikut.

1. Hasil penelitian menunjukkan bahwa konten yang menggunakan visual aesthetics classical akan menghasilkan persepsi terhadap information credibility lebih positif, dibandingkan konten iklan yang menggunakan visual aesthetics expressive.

2. Hasil penelitian menunjukkan bahwa konten yang penggunaan desain visual aesthetics classical akan menghasilkan consumer trust lebih positif, dibandingkan penggunaan iklan dengan desain visual aesthetics expressive.

3. Hasil penelitian menunjukkan bahwa konten dengan tampilan multiple presentation modality berupa video akan menghasilkan persepsi terhadap information credibility lebih positif, dibandingkan konten periklanan dengan tampilan single presentation modality berupa gambar.

4. Hasil penelitian menunjukkan bahwa konten dengan tampilan multiple presentation modality berupa video akan menghasilkan consumer trust lebih tinggi, dibandingkan konten periklanan dengan tampilan single presentation modality berupa gambar.
5. Hasil penelitian menunjukkan bahwa information credibility berpengaruh positif terhadap consumer trust.

6. Hasil penelitian menunjukkan bahwa information credibility berpengaruh positif terhadap purchase intention.

7. Hasil penelitian menunjukkan bahwa consumer trust berpengaruh positif terhadap purchase intention.

\section{IMPLIKASI PENELITIAN}

Sebagai suatu penelitian maka kesimpulan yang ditarik tentu mempunyai suatu implikasi. Dalam studi ini terdapat dua implikasi yang dapat dirasakan oleh pihak akademisi dan perusahaan. Penjelasan mengenai kedua implikasi tersebut akan dijabarkan sebagai berikut.

\section{Bagi Pihak Akademisi}

Penelitian ini memberikan kontribusi akademis pada bidang komunikasi pemasaran. Selama ini, penelitian mengenai strategi penggunaan $v i$ sual aesthetics dan presentation modality lebih banyak diulas pada konteks tampilan website. Maka dari itu, penelitian ini diharapkan akan menambah literatur mengenai efektivitas visual aesthetics dan presentation modality pada tampilan konten iklan di media sosial Instagram. Oleh karena itu, temuan ini diharapkan dapat memberikan kontribusi mengenai efektivitas konten iklan di Instagram menggunakan strategi visual aesthetics dan presentation modality terutama jenis classical visual aesthetics dan multiple presentation modality.

\section{Bagi Pihak Pemasar}

Penelitian ini memberikan kontribusi bagi pemasar dalam hal strategi perancangan konten 
iklan yang berfokus pada jenis visual aesthetics dan presentation modality. Temuan penelitian ini menyatakan bahwa konten iklan dengan classical visual aesthetics dan multiple presentation modality mampu menghasilkan information credibility dan consumer trust lebih positif. Bagi pengusaha makanan temuan ini berkontribusi untuk merancang strategi yang tepat dalam membuat konten iklan di Instagram. Dengan demikian, disarankan bagi pengusaha makanan untuk menggunakan jenis classical visual aesthetics dan multiple presentation modality. Apabila konten yang dibuat oleh pengusaha makanan tepat maka akan menghasilkan information credibility dan consumer trust yang positif dari pengguna Instagram.

\section{DAFTAR RUJUKAN}

Ahmed, M. \& Abdulwahid, N. 2012. Endorser Credibility Effects on Yemeni Male Consumer's Attitudes towards Advertising, Brand Attitude and Purchase Intention: The Mediating Role of Attitude toward Brand. International Business Research, Vol. 5, No 4, April 2012.

Barlow, T. \& Wogalter, M.S. 1993. Alcoholic beverage warnings in magazine and television advertisements. Journal Consum, Res. 20.

Belch, P.T., Brunel, F.F., \& Arnold, T.J. 2004. Individual differences in the centrality of visual product aesthetics: Concept and measurement. Journal of Consumer Research 29, 551-565.

Burgoon, J.K., Blair, J.P., \& Strom, R.E. 2008. Cognitive biases and nonverbal cue availability in detecting deception. Human Communication Research, 34, 572-599.
Bloch, P.T., Brunel, F.F., \& Arnold, T.J. 2003. Individual differences in the centrality of visual product aesthetics: Concept and measurement. Journal of Consumer Research, 29, 551--565.

Curwin, N., Moultrie, J., \& Clarkson, P.J. 2002. Seeing things: consumer response to the visual domain in product design. Elsevier Design Studies, 25, 547-577.

Crilly, N., Moultrie, J., \& Clarkson, P.J. 2004. Seeing things: consumer response to the visual domain in product design. Elsevier Design Studies, 25, 547-577.

Femaledaily.com. 2018. Intip Keseruan Launching dan Blogger Gathering WardahInstaperfect.[http://editorial.femaledaily.com/ blog/2018/08/15/intip-keseruan-launchingdan-blogger-gathering-wardah-instaperfect/]. Diakses pada 12 Oktober.

Goldsmith, M. \& Hassanein, K. 2000. Consumers' Satisfaction with Online Information Quality: The Moderating Roles of Consumer Decision-Making Style, Gender and Product Involvement. ECIS 2013 Research in Progress, 10.

Goldsmith, R.E., Bridges, E., \& Freiden, J. 2002. Characterizing online buyers: who goes with the flow? Quarterly Journal of Electronic Commerce, Vol. 2, No. 3, pp. 189-197.

Ghozali, Imam. 2014. Structural Equation Modelling, Metode Alternatif dengan Partial Least Square (PLS), Edisi 4. Semarang: Badan Penerbit Universitas Diponegoro.

Horton, D.L. \& Thomas P.N. 1984. Marketing in Hypermedia Computer-Mediated Environments: Conceptual Foundations. Journal of Marketing, 60, 50-68.

Hootsuite. 2018. Digital Report 2018. Web. Diakses November 2019. 
Ismagilova, Elvira. 2019. The effect of characteristics of source credibility on consumer behaviour: A meta-analysis. Journal of Retailing and Consumer Services.

Kensicki, L.J. 2003. Building credibility for nonprofit organizations through Webpage interface design. Journal of Visual Literacy, 23, 139-162.

Kompas.com. 2018. Pengguna Aktif Instagram Tembus 1 Miliar. [https://tekno.kompas. com/read/2018/06/21/10280037/juni-2018pengguna-aktif-instagram-tembus-1-miliar] Diakses pada 5 November 2018.

Kristensen, T., Gabrielsen, G., Zaichkowsky, J.L. 2012. How valuable is a well-crafted design and name brand? Recognition and willingness to pay. Journal of Consumer Behavior, 11, 44-55.

Marketeers.com. 2017. Media Insight dari 45 Juta Pengguna Aktif Instagram di Indonesia. [http://marketeers.com/45-juta-orangindonesia-punya instagra $\mathrm{m} / \mathrm{]}$. Diakses pada 5 Februari 2019.

Mcknight, E., Richard, M.O., \& Laroche, M. 2002. Online consumer behavior: comparing Canadian and Chinese website visitors. Journal of Business Research, Vol. 64 (9), 958-965.

Mix.co.id. 2017. Mengapa Iklan Berbayar di Media Sosial Lebih Efektif. [http://mix.co. $\mathrm{id} / \mathrm{marcomm} /$ brand-communication/adver- tising/mengapai-iklan-berbayar-di-socialmedia-lebih-efektif]. Diakses pada $10 \mathrm{Ok}$ tober 2018.

Mix.com. 2018. Strategi Influencer Marketing Makin Diminati. [https://mix.co.id/marcomm/brand-insight/marketing-strategy/ 2018-strategi-influencer-marketing-makindiminati]. Diakses pada 29 Oktober 2018.

Nekmat, E. \& Gower, K.K. 2018. Effects of Disclosure and Message Valence in Online Word-of-Mouth (eWOM) Communication: Implications for Integrated Marketing Communication. International Journal of Integrated Marketing Communications. Rodríguez-Ardura, I. \& Martínez-López, F.J. 2008. Playing cat and mouse: consumer empowerment and marketing interaction on the net. International Journal of Business Environment, Vol. 2, No. 2, pp. 201214.

Stafford, N. \& Singh, S.N. 2004. Measuring attitude toward the brand and purchase intentions. Journal of Current Issues and Research in Advertising, Vol. 26(2), 5366.

Urban, J.J. \& Chang, Y.S. 2009. Towards Understanding Members' Interactivity, Trust, and Flow in Online Travel Community. Industrial Management \& Data Systems, Vol. 105(7): 937-954. 